\title{
Toxicological and Electrophysiological Activities of Tralomethrin and Deltamethrin against Larvae of Tobacco Cutworm, Spodoptera litura
}

\author{
Makoto Hatakoshi, Kimitoshi Umeda, Tadashi Ohsumi, \\ Nobushige Itaya and Isamu Nakayama \\ Pesticides Research Laboratory, Takarazuka Research Center, \\ Sumitomo Chemical Co., Ltd., Takatsukasa, Takarazuka 665, Japan
}

(Received October 11, 1985)

\begin{abstract}
The biological activity of tralomethrin against larvae of the tobacco cutworm, Spodoptera litura, was evaluated by injection, topical application and electrophysiological studies, and compared to that of deltamethrin. By injection, tralomethrin was almost as potent as deltamethrin. By topical application, tralomethrin delayed the onset of moribund symptoms longer than deltamethrin. Tralomethrin increased miniature excitatory postsynaptic potentials at neuromuscular junctions less often than deltamethrin. The electrophysiological studies suggested that tralomethrin per se was less active than deltamethrin at the target site. The observed in vivo activities of tralomethrin may have arised from deltamethrin present in tralomethrin samples, or from deltamethrin converted from tralomethrin in the insect, or from both.
\end{abstract}

\section{INTRODUCTION}

Tralomethrin $[(S)-\alpha$-cyano-3-phenoxybenzyl $\left(1^{\prime} R S\right)$-cis- $(1 R, 3 R)-3-(1,2,2,2$-tetrabromoethyl)-2,2-dimethylcyclopropanecarboxylate], like deltamethrin $[(S)$ - $\alpha$-cyano-3-phenoxybenzyl (1R, 3R)-3-(2, 2-dibromovinyl)-2, 2-dimethylcyclopropanecarboxylate], is highly insecticidal and toxic to mammals. ${ }^{1-3)}$ However, tralomethrin is readily debrominated into deltamethrin in the bodies of insects ${ }^{4}$ and rats $^{2)}$ and by ultraviolet light. ${ }^{5)}$ Thus, the insecticidal activity of tralomethrin is assumed to arise from deltamethrin contained in the tralomethrin sample as an impurity, or from deltamethrin produced through nonenzymatic debromination of tralomethrin., ${ }^{2,4)}$ Kaneko et al. have found that tralomethrin is converted to deltamethrin inside the larvae of tobacco cutworms much more quickly than on the larval surface. ${ }^{6)}$ Electrophysiological studies using insect nerve-muscle preparations show that tralomethrin per se is inactive in Heliothis virescens, Chilo partellus, and Plutella xylostella. ${ }^{7)}$

This experiment was to see whether tralomethrin per se has any activity by injecting or topically applying the compound to the tobacco cutworm, Spodoptera litura, a serious pest of vegetables. Electrophysiological methods were also used for the experiment.

\section{MATERIALS AND METHODS}

\section{Chemicals}

Deltamethrin was prepared by the method of Elliott et al. ${ }^{8)}$ The purity of the compound was $99.5 \%$. Tralomethrin was prepared as follows: to a solution of deltamethrin $(3.00 \mathrm{~g})$ in $\mathrm{CCl}_{4}(15 \mathrm{ml})$, a solution of bromine $(1.05 \mathrm{~g})$ in $\mathrm{CCl}_{4}(5 \mathrm{ml})$ was added with stirring at $0^{\circ} \mathrm{C}$ and the mixture was stirred for $3 \mathrm{hr}$ at room temperature. The resulting solution was concentrated at room temperature under reduced pressure and the residue was chromatographed on silica gel (eluent, $n$-hexane: ethyl acetate, $85: 15, \mathrm{v} / \mathrm{v})$ to give tralomethrin $(4.80 \mathrm{~g})$ as a 
mixture of diastereoisomers, that separated into two spots on thin-layer chromatography of silica gel with the solvent system of $n$-hexane: ethyl acetate $(88: 12, \mathrm{v} / \mathrm{v})$. Here, the compounds with higher and lower $R f$ values were named tralomethrin $\mathrm{A}$ and $\mathrm{B}$, respectively. They were identified as diastereoisomers of tralomethrin by proton magnetic resonance and mass spectrometry. The purity of tralomethrin and the mixture ratio of $\mathrm{A}$ and $\mathrm{B}$ were determined by high-performance liquid chromatography [column, Lichrosorb SI-60; mobile phase, $n$-hexane: $n$-pentane : dioxane : acetonitrile : isopropanol $(900: 90: 30: 14: 0.15, \mathrm{v} / \mathrm{v})]$. Sample 1: tralomethrin A $(99.5 \%$, deltamethrin $0.0 \%$ )

Sample 2: mixture of tralomethrin $\mathrm{A}$ and $\mathrm{B}$ $(\mathrm{A} / \mathrm{B}=1 / 1$, deltamethrin $0.4 \%)$

Sample 3: mixture of tralomethrin $\mathrm{A}$ and $\mathrm{B}$ $(\mathrm{A} / \mathrm{B}=1 / 1$, deltamethrin $0.9 \%)$

\section{Injection}

One microliter of ethanol solution of each compound was injected subcutaneously into the abdominal cavity of the sixth (last) instar larvae of $S$. litura (mean weight: $0.689 \pm 0.026$ g) through the first proleg with a microsyringe under mild $\mathrm{CO}_{2}$ anesthesia. The insects were kept in a plastic cup at $25^{\circ} \mathrm{C}$ and their symptoms were observed. Ethanol in this volume did not have any toxic effect. Five larvae were used for each test.

\section{Topical Application}

One microliter of the acetone solution of each sample of tralomethrin (samples 1 and 2) or deltamethrin was topically applied to the dorsal surface of the third instar larvae of S. litura (mean weight: $0.0362 \pm 0.0031 \mathrm{~g}$ ) with a glass capillary without anesthesia. The tralomethrin solution was prepared immediately before each experiment. The insects were placed in a plastic cup at $25^{\circ} \mathrm{C}$ and their symptoms were observed. Acetone in this volume produced no toxic effect. Ten larvae were used for each test.

\section{Electrophysiological Studies}

Electrophysiological experiments were performed with intersegmental longitudinal muscle fibers of the sixth instar larvae of the tobacco cutworm, which were innervated by moto-
A

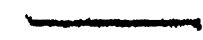

C

B


Fig. 1 Miniature excitatory postsynaptic potentials (mEPSP) recorded intracellularly from longitudinal muscles of $S$. litura.

(A)-(D) are typical recordings of mEPSP before (A) and after (B) application of $5 \times 10^{-8} \mathrm{M}$ deltamethrin, and before (C) and after (D) application of $1 \times 10^{-6} \mathrm{M}$ tralomethrin $\mathrm{A}$ and $\mathrm{B}$ (sample 3 ). Calibrations: $1 \mathrm{mV}, 0.2 \mathrm{sec}$.

neurons originating from the third abdominal ganglion. ${ }^{9)} \quad$ To estimate the effects of the chemicals on the neuromuscular junctions the miniature excitatory postsynaptic potentials (mEPSP) were measured as described before. $^{7,10)}$ Insects were mounted the ventral side up on a paraffin plate and dissected by ventral incision. The alimentary canal and the associated fat bodies were removed, exposing the nervous system and the dorsal muscle fibers. The nerve-muscle preparation was immersed in physiological saline containing 150 $\mathrm{mm} \mathrm{NaCl}, 3 \mathrm{~mm} \mathrm{KCl}$ and $3 \mathrm{~mm} \mathrm{CaCl}_{2}, \mathrm{pH}$ 6.6. The mEPSP was measured using a glass microelectrode filled with $3 \mathrm{~m} \mathrm{KCl}$ whose resistance was 5-10 M $\Omega$. After recording the mEPSPs in normal saline (Figs. 1A and C), the saline was changed to the test solution. The chemicals (sample 3 and deltamethrin) were dissolved in dimethyl sulfoxide $\left(\mathrm{Me}_{2} \mathrm{SO}\right)$ at the concentration of $1 \times 10^{-2} \mathrm{M}$ and diluted in saline to a desired concentration before the experiments. The final concentration of $\mathrm{Me}_{2} \mathrm{SO}$ was less than $0.1 \%(\mathrm{v} / \mathrm{v})$, which did not affect the preparations. The preparation was incubated in the test solution for $10 \mathrm{~min}$ in the dark to minimize the photodebromination of tralomethrin. Then the solution was changed to fresh saline to find the percentage of fibers with mEPSP of increased frequency (Figs. 1B and D). Ten fibers for each larva were pierced and measured for about $1 \mathrm{~min}$. The criterion of Irving and Fraser ${ }^{7)}$ was employed for the measurement of increased frequency of the mEPSP. For each test sample, 3-9 larvae were used. All experiments were carried out at room temperature $\left(20-25^{\circ} \mathrm{C}\right)$. 


\section{RESULTS}

When tralomethrin and deltamethrin were injected or topically applied to the larvae of $S$. litura, typical symptoms were: first, anomalous movement and occasional vomiting of digestive juice, then slight convulsion, and occasional violent twisting of the body, followed by stop of all movements. Slight convulsion was regarded as the moribund symptom, as it is the first distinct sign of toxicity.

The onset of the moribund symptom observed in the sixth instar larvae after tralomethrin A (sample 1) or deltamethrin was injected is shown in Fig. 2. Six minutes after injection of $1.5 \times 10^{-12} \mathrm{~mol}$ of tralomethrin $\mathrm{A}$, larvae showed the moribund symptom. Larvae treated with $1.5 \times 10^{-13}$ or $1.5 \times 10^{-14} \mathrm{~mol}$ of tralomethrin A developed symptoms after 14.8 and $28.0 \mathrm{~min}$, respectively. Injection of $2.0 \times 10^{-12} \mathrm{~mol}, 2.0 \times 10^{-13} \mathrm{~mol}$, and $2.0 \times 10^{-14}$ mol of deltamethrin induced the moribund symptom after $4.6,10.0$, and $23.8 \mathrm{~min}$, respectively. The onset of the symptom varied depending on the dosage. Regression lines for both compounds were linear at the level of $95 \%$ by the $F$-test [tralomethrin A, $F_{\text {cal }}=15.50>$ $F_{0.05}(1,13)=4.67$; deltamethrin, $F_{\text {eal }}=12.49>$ $\left.F_{0.05}(1,13)=4.67\right]$, and parallel $\left[t_{\text {cal }}=0.40<\right.$ $\left.t_{0.05}(26)=2.06\right]$. The potency of tralomethrin A (sample 1) relative to that of deltamethrin was 0.6 .

The onset of the moribund symptom observed in the third instar larvae when tralomethrin A (sample 1), tralomethrin A and B (sample 2), and deltamethrin were topically applied is shown in Fig. 3. Larvae treated with $1.5 \times 10^{-7} \mathrm{~mol}$ of tralomethrin $\mathrm{A}$ or $1.5 \times 10^{-8}$ mol of tralomethrin A and B developed the moribund symptom after 13.0 and $12.9 \mathrm{~min}$, respectively. The symptom appeared slower than when $5.9 \times 10^{-11} \mathrm{~mol}$ of deltamethrin was applied $(11.4 \mathrm{~min})$. Regression lines were calculated in the same manner as for the injections. Linearity of the regression lines of the three compounds was shown by the $F$-test to be at the level of $95 \%$ [tralomethrin A, $F_{\text {cal }}=$ $6.25>F_{0.05}(1,18)=4.41$; tralomethrin $\mathrm{A}$ and B, $\quad F_{\text {cal }}=17.70>F_{0.05}(1,28)=4.20 ; \quad$ deltamethrin: $\left.F_{\text {cal }}=15.80>F_{0.05}(1,48)=4.04\right]$. The regression lines of tralomethrin A (sample 1)

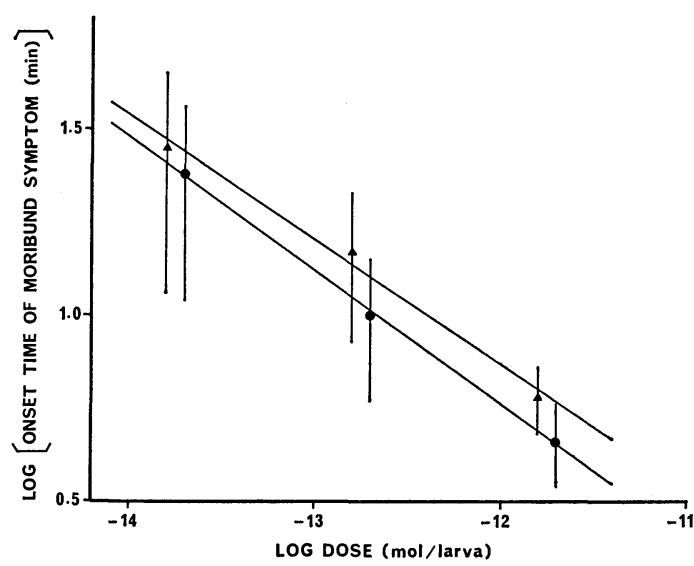

Fig. 2 Dose-response relationship of tralomethrin A (sample 1, $\mathbf{A}$ ) and deltamethrin () in giving rise to moribund symptoms in sixth instar larvae of S. litura by injection.

Both compounds were dissolved in ethanol. Each point represents the mean \pm S.D. $(n=5)$.

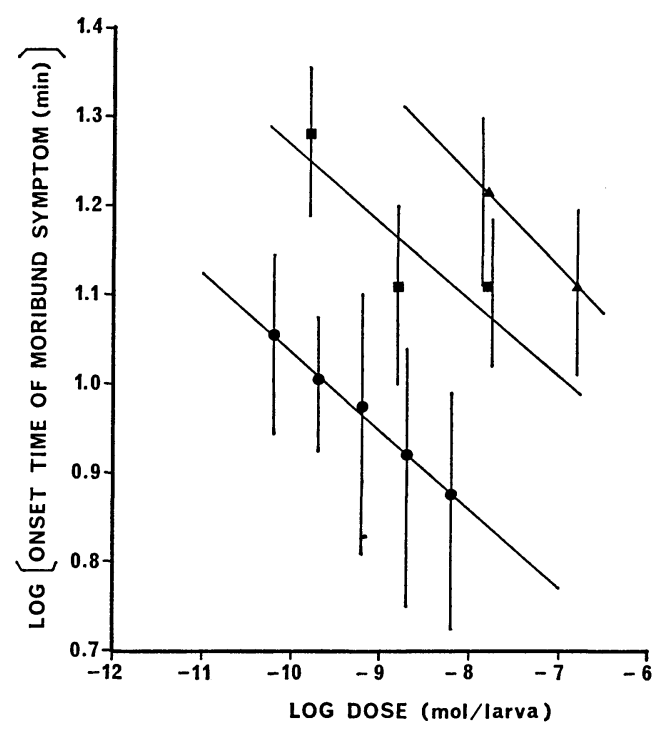

Fig. 3 Dose-response relationship of tralomethrin A (sample 1, $\mathbf{\Delta}$ ), tralomethrin A and B (sample 2, $\mathbf{\square}$ ), and deltamethrin (○) in giving rise to moribund symptoms in third instar larvae of S. litura by topical application.

The three preparations were dissolved in acetone. Each point represents the mean \pm S.D. $(n=10)$.

and deltamethrin were parallel by the $t$-test at the level of $95 \% \quad\left[t_{\text {cal }}=1.22<t_{0.05}(66)=2.00\right]$, and so were the regression lines of tralomethrin 


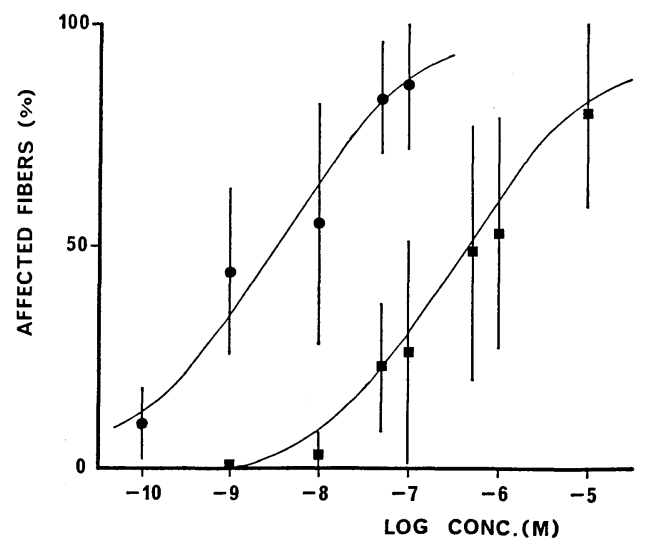

Fig. 4 Dose-response relationship of tralomethrin A and B (sample 3, $\mathbf{a}$ ) and deltamethrin (๑) in increasing the frequency of mEPSP.

Each point represents the percentage of affected fibers. $\mathrm{Me}_{2} \mathrm{SO}$ is a solvent of the stock solution. Each point represents the mean \pm S.D. $(n=3-9)$.

A and B (sample 2) and deltamethrin $\left(t_{\mathrm{cal}}=\right.$ $\left.1.43<t_{0.05}(76)=2.00\right]$. The potency of tralomethrin A (sample 1) and tralomethrin A and $\mathrm{B}$ (sample 2) relative to that of deltamethrin was 0.00004 and 0.002 , respectively.

The effects of tralomethrin A and B (sample 3) and deltamethrin on the preparations of neuromuscular junctions are shown in Figs. 1 and 4. Tralomethrin did not increase the frequency of mEPSP at $1 \times 10^{-9} \mathrm{M}$, but deltamethrin did by $10 \%$ at $1 \times 10^{-10} \mathrm{M}$. The percentage of fibers with increased frequency of mEPSP raised sigmoidally as the concentration of each test compound increased. The dose-response curves in Fig. 4 show that the concentration needed to increase the response by $50 \%$ was $6.3 \times 10^{-7} \mathrm{M}$ for tralomethrin $\mathrm{A}$ and $\mathrm{B}$ (sample 3 ) and $5.0 \times 10^{-9} \mathrm{M}$ for deltamethrin.

\section{DISCUSSION}

The timing of onset of the moribund symptom by injection of tralomethrin A was close to that of deltamethrin. By topical application, however, the activities of tralomethrin $\mathrm{A}$ and of tralomethrin $\mathrm{A}$ and $\mathrm{B}$ together were much lower than the activity of deltamethrin. This discrepancy in the data obtained with two different application methods could be explained by an assumption that the intrinsic activities of tralomethrin and deltamethrin are almost the same at the target site, but the penetration of tralomethrin through the integument is much slower than that of deltamethrin. However, Kaneko et al. report that there is little difference in penetration rates between tralomethrin A and deltamethrin. ${ }^{6)}$ Also as will be mentioned, the activity of tralomethrin $\mathrm{A}$ and $\mathrm{B}$ on the preparations of neuromuscular junctions was much lower than that of deltamethrin.

Tralomethrin is easily debrominated to deltamethrin in insects by the action of compounds with thiol groups such as glutathione and cysteine. ${ }^{3,4)}$ In S. litura, topically applied tralomethrin can be converted to deltamethrin inside the body. ${ }^{6}$ ) The reason why tralomethrin acts more slowly than deltamethrin when topically applied is not clear, but tralomethrin might be converted by thiol group compounds to deltamethrin much faster in the haemolymph than on the cuticle, in the integument and in the nerve-muscle organs that are the site of action of deltamethrin. ${ }^{3)}$

The effects of tralomethrin on preparations of neuromuscular junctions were compared with those of deltamethrin. By use of these preparations, the accurate activities of these chemicals could be evaluated since the conversion of tralomethrin to deltamethrin is minimized and transportation from the site of application to the site of action can be ignored. Tralomethrin A and B (sample 3) were not as potent as deltamethrin to increase the mEPSP at the neuromuscular junctions. Irving and Fraser found that tralomethrin per se has no activity by studying the effects of tralomethrin and deltamethrin on the muscle fibers of larvae of $H$. virescens, C. partellus, and P. xylostella. ${ }^{7)}$ Our results with neuromuscular preparations of larvae of S. litura were consistant with their findings.

Our conclusion is that the biological activity of tralomethrin per se is extremely low, and that the apparent activity may in fact arise from deltamethrin included in tralomethrin samples or converted from tralomethrin in the body of the tobacco cutworm.

\section{REFERENCES}

1) J. J. Herve, M. Benoit, M. Roche \& P. Housset: 
Roussel-Uclaf French Demande 2364884 (1978)

2) L. M. Cole, L. O. Ruzo, E. J. Wood \&. J. E. Casida: J. Agric. Food Chem. 30, 631 (1982)

3) D. W. Gammon \& L. O. Ruzo: Pestic. Sci. 15, 586 (1984)

4) L. O. Ruzo, L. C. Gaughan \& J. E. Casida: Pestic. Biochem. Physiol. 15, 137 (1981)

5) L. O. Ruzo \& J. E. Casida: J. Agric. Food Chem. 29, 702 (1981)

6) H. Kaneko, Y. Takamatsu, N. Kitamura, A. Yoshitake \& J. Miyamoto: J. Pesticide Sci. 11, 533 (1986)

7) S. N. Irving \& T. E. M. Fraser: J. Agric. Food Chem. 32, 111 (1984)

8) M. Elliott, A. W. Farnham, N. F. Janes, P. H. Needham \& D. A. Pulman: Nature (London) 248, 710 (1974)

9) P. Belton: J. Insect Physiol. 15, 731 (1969)

10) V. L. Salgado, S. N. Irving \& T. A. Miller: Pestic. Biochem. Physiol. 20, 100 (1983)
要 約

\section{ハスモンョトウ幼虫に対する tralomethrin と deltamethrin の毒性および電気生理学的活性}

波多腰信，梅田公利，大住忠司 板谷信重, 中山 勇

ハスモンヨトウ幼忠に対する tralomethrin[ $(S)$ - $\alpha$-cyano-3-phenoxybenzyl ( $\left.1^{\prime} R S\right)$-cis-(1R,3R)-3-(1,2,2,2-tetrabromoethyl)-2,2-dimethylcyclopropanecarboxylate] , 注 射法, 局所施用法による毒性および電気生理学的方法に よる神経系に対する活性を調べ, deltamethrin $[(S)-\alpha$-cyano-3-phenoxybenzyl (1R,3R)-3-(2,2-dibromovinyl)-2,2dimethylcyclopropanecarboxylate] のそれと比較検討し た. 注射法では, tralomethrin は deltamethrin とほぼ同 等の活性を示した. しかし，局所施用法では tralomethrin の活性は deltamethrin のそれに比べ著しく弱いもの であった. 神経筋接合部に対する電気生理学的実験によ っても, tralomethrin の活性は微弱であった. 観察され た in vivo の活性は, tralomethrin サンプル中の deltamethrin により，または昆虫体内において tralomethrin より変換された deltamethrinにより生じたと思われる. 